\title{
References
}

Allaart, J. H., Friend, C. R. L., Hall, R. P., Jensen, S. B. \& Roberts, I. W. N. 1978: Continued 1:500 000 reconnaissance mapping in the Precambrian of the Sukkertoppen region, southern West Greenland. Rapp. Grønlands geol. Unders. 90, 50-54.

Hall, R. P. 1980: The tholeiitic and komatiitic affinities of the Malene metavolcanic amphibolites from Ivisârtoq, southern West Greenland. Rapp. Grønlands geol. Unders. 97, 20 pp.

Department of Geology, Portsmouth Polytechnic, Burnaby Road,

Portsmouth PO1 $3 Q L$,

U.K.

\section{Further work on the early Archaean rocks of the Isukasia area, southern West Greenland}

\section{A. P. Nutman}

Work in 1981 on the early Archaean rocks of the Isukasia area (Allaart, 1976) was an integral part of GGU's mapping programme of northern Godthåbsfjord, Fiskefjord and adjacent areas to the north-east. Within the Isukasia area, there was close co-operation with Minik Rosing who was making detailed studies of certain aspects of the Isua supracrustal belt.

The object of this summer's field work was to complete the study of the supracrustal belt and the central gneisses that was started last year (Nutman et al., in press), and to see as much as possible of the gneisses between the supracrustal belt and $65^{\circ} \mathrm{N}$ (fig. 18). For the mapping of the supracrustal belt, manuscript maps drawn by J. H. Allaart were an invaluable starting point. Besides regional mapping, detailed studies were made of the nature of the lithological units and the relationships between them; see Table 4 for chronology. Suites of rocks were collected for isotopic and geochemical studies. In connection with this, $\mathbf{H}$. Baadsgaard spent 10 days working with the author in the area, as a guest of GGU.

The results reported here supplement those given by Nutman et al. (in press).

\section{Supracrustal rocks}

The stratigraphic sequence for the Isua supracrustal belt (fig. 19), erected on the basis of the part visited in 1980, is applicable throughout the belt. For Sequence A, the upper and middle parts are predominantly banded felsic rocks (some demonstrably of detrital origin) and chemical sediments. The lowest parts, which are only well-developed in the west, are predominantly banded amphibolites, probably of volcanogenic origin. In the far north-east

4 Rapport nr. 110 


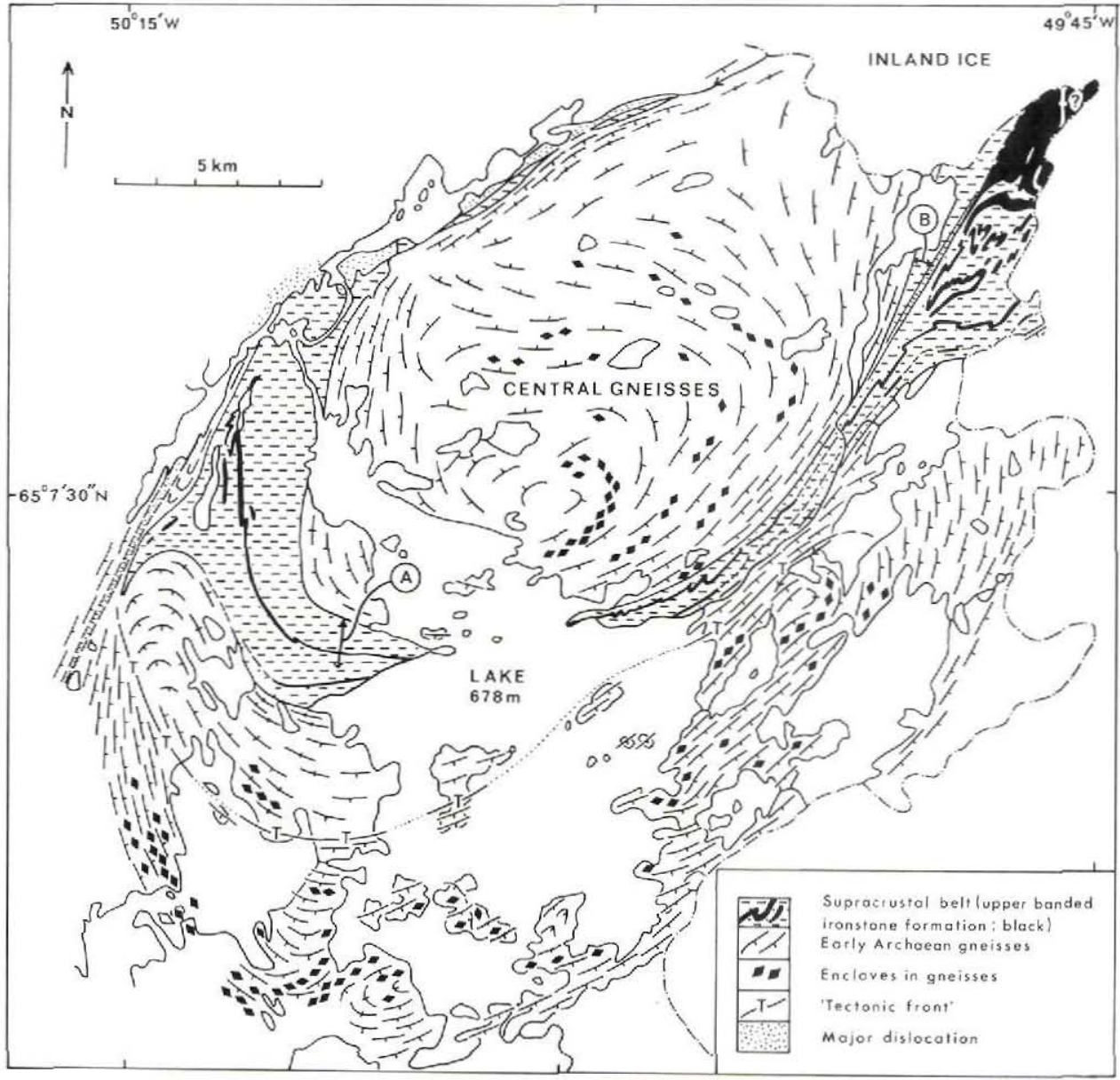

Fig. 18. Geological sketch map of the Isukasia area. A and B are the location of the stratigraphic columns shown on fig. 19.

of the belt (fig. 18) there is no profound tectonic break apparent between the upper banded iron formation of Sequence A and underlying Sequence B. This supports the favoured correlation between Sequences A and B (Nutman et al., in press).

\section{Enclaves in the gneisses enveloping the supracrustal belt}

In the gneisses enveloping the supracrustal belt there are discontinuous agmatite trains of banded amphibolites, banded iron formation, ultramafic rocks and coarse-grained hornblende clinopyroxenite. Except for the latter, they all lithologically match rocks of the lower parts of the Isua supracrustal belt stratigraphy. At one locality south of the supracrustal belt 
Table 4. Geological events on the basis that all the gneisses are younger than the supracrustal rocks and all the Tarssarto q dykes are equivalent to the Ameralik dykes

(1) Thermal event (greenschist facies) and local emplacement of crustally derived granitic sheets

c. $1600 \mathrm{Ma}$

$2100 \mathrm{Ma}$ ?

(2) Intrusion of basic dykes

(3) Intrusion of pegmatites

(4) Deformation (equivalent of D2 to D4 south of Godthåb?) for example manifested by the rotation or tightening of structures to give the supracrustal belt its arcuate shape. Metamorphism up to amphibolite facies. Intrusion of a few pegmatitic gneiss sheets south of the supracrustal belt

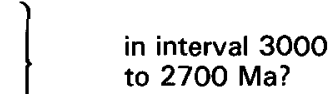

(5) Intrusion of Tarssartôq dykes

(6) Deformation (most severe in the south) and amphibolite facies metamorphism. Formation of D1c antiform in the central gneisses?

(7) Intrusion of thin grey sheets

(8) Intrusion of the white gneisses, with deformation (D1b) including tectonisation of grey gneiss - supracrustal rock contacts

(9) Intrusion of Inaluk dykes and mafic-ultramafic net vein complexes

(10) Intrusion of early thin grey sheets

(11) Intrusion of the grey gneisses; probably penecontemperaneous with isoclinal folding in the supracrustal rocks (D1a), and probably accompanied by amphibolite facies metamorphism

(12) Deposition of the Isua supracrustal sequence and emplacement of ultramafic and leucogabbroic sills
All or some in interval 3750

to $3500 \mathrm{Ma}$

the coarse-grained hornblende clinopyroxenites net vein (and contain inclusions of) grey gneiss and are agmatised by white gneiss. This suggests that they are an 'intra-Amîtsoq' mafic-ultramafic net vein complex, rather than altered supracrustal rocks (Nutman et al., in press).

\section{The gneisses; their chronology and relation with supracrustal rocks}

In the north-east of the central gneisses (fig. 18) there is a large lenticular body of white gneiss, which southwards breaks up into a swarm of originally flat-lying sheets anastomosing throughout the older grey gneisses cut by Inaluk dykes (Nutman et al., in press). In contrast, the north-western margin of the central gneisses is relatively free of white gneiss sheets and comprises homogeneous, grey granodiorite-tonalite. Contacts between grey phases of the central gneisses and supracrustal rocks that have not been obscured by white gneiss sheeting are normally sharp and concordant, and the contact grey gneisses have a fine-grained augenflaser texture. Such contacts are probably tectonic. Enclaves of supracrustal rocks in grey central gneisses are rare. 


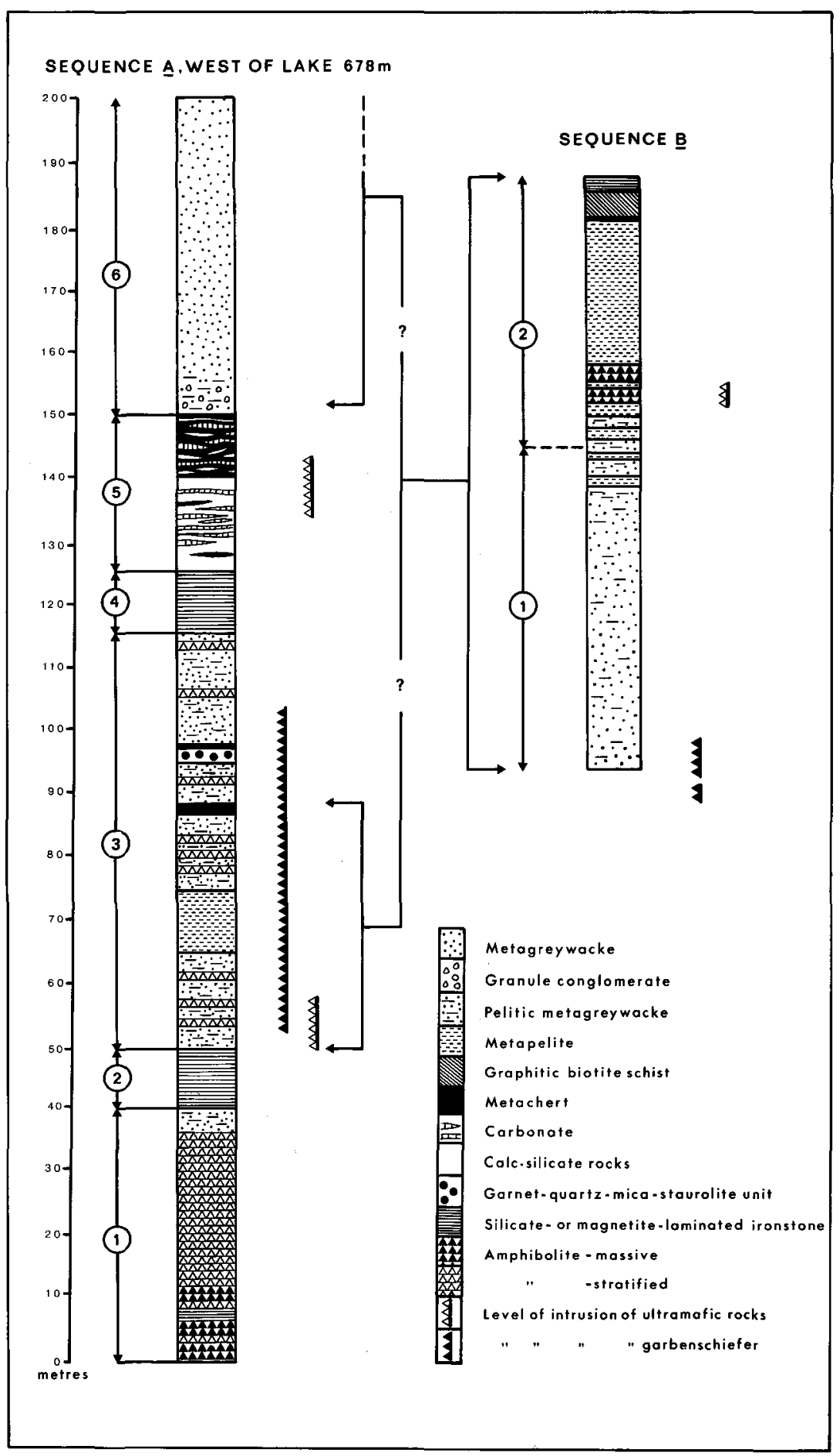


South of the supracrustal belt grey gneisses form a higher proportion of the gneiss complex. They migmatise supracrustal rocks and are locally cut by Inaluk dykes prior to being sheeted by white gneiss.

Thus, the gneiss chronology (Table 4) has been confirmed in all parts of the area where gneisses have not been strongly tectonometamorphically modified. The interlayering of supracrustal rocks and gneisses is a function of both style of intrusion of the precursors of the gneisses and tectonic interleaving.

\section{Tectonometamorphic history}

South of the supracrustal belt deformed grey and white gneiss migmatites are further modified into banded gneiss in which individual phases cannot be distinguished with confidence. In extreme cases the gneisses become schlieric - interpreted as having been reconstituted in a mobile state. These changes normally take place over less than $2 \mathrm{~km}$, a sharp enough transition to be described as a tectonic front. This front runs obliquely to the trend of the supracrustal belt (fig. 18) and south of it augen of less deformed gneisses, in which individual phases can be identified, comprise less than 15 per cent of outcrop. Southwards, the Tarssartôq dykes (Table 1) are also progressively more deformed, becoming lineated, foliated, tectonically thinned, and depending on their orientation, boudinaged or folded. The Tarssartôq dykes do not undergo rapid modification across the tectonic front in the gneisses, showing that the high strain recorded by the gneisses in the south is the manifestation of a blend of post- and pre-Tarssartôq-dyke deformation. South of the tectonic front there are tracts of small intrafolial isoclinal folds in the gneisses, locally seen to be refolded by folds trending approximately north-south with vertical axial surfaces and southerly plunging axes. There are also larger-scale irregularities in the trend of gneiss banding, Tarssartôq dykes and amphibolite enclave trains, suggesting the presence of large isoclinal folds in the gneisses, modified by folds with north-south trending axes.

South of the tectonic front supracrustal enclaves in the gneisses show evidence of considerable metamorphic segregation/incipient partial melting under at least middle amphibolite facies conditions. Cross-cutting Tarssartôq dykes are homogeneous hornblende-plagioclase amphibolites with $L S$ fabric. Rocks of the supracrustal belt and equivalent lithologies occurring as enclaves in the central gneisses commonly have relict amphibolite facies assemblages, with local metamorphic segregation and/or incipient partial melt sweats; whilst cross-cutting Tarssartôq dykes (depending on the degree of post-dyke strain) have been recrystallised under amphibolite facies conditions or are altered dolerites. These relations suggest that there was widespread pre-Tarssartôq-dyke amphibolite facies metamorphism, and that recrystallisation during a post-Tarssartôq-dyke tectonometamorphic event was more extensive southwards.

Garbenschiefer texture, normally of amphibole, is widespread throughout the area, particularly in the north-west. It occurs in all lithologies of the supracrustal belt, but is best

Fig. 19. Schematic stratigraphic columns of the Isua supracrustal belt (localities shown on fig. 18). Sequence A: 1 to 6 are the amphibolite formation, lower banded iron formation, variegated schist formation, upper banded iron formation, calc-silicate formation and felsic formation respectively. Sequence B: 1 and 2 are the felsic formation and mica schist formation respectively. The two most likely alternative correlations between sequences $\mathrm{A}$ and $\mathrm{B}$ are indicated by means of square brackets. 
developed in the garbenschiefer unit (a chloritic leucoamphibolite) and amphibole-rich rocks of the calc-silicate formation. Garbenschiefer texture also occurs locally in Tarssartôq dykes. In the orthogneisses of the north-western part of the area hornfelsic and decussate textures are locally developed. These are believed to be equivalent to the garbenschiefer texture in other litholigies. The garbenschiefer and related textures overprint and locally obliterate older mineral lineations, but have not been found in rocks affected by the late dislocations discussed below. These textures indicate a period of static heating late in the area's history, which apparently was most severe in the north-west.

After post-Tarssartôq-dyke amphibolite facies metamorphism, rocks of the northern and north-western fringes of the area were extensively recrystallised under greenschist facies conditions. Probably associated with this is the extensive redistribution in both vein and disseminated form of carbonate, graphite and sulphide(s) in this part of the area, suggesting the rocks were permeated by mobile impure fluid phases. A major dislocation dipping $20^{\circ}$ to $50^{\circ}$ to the east or south-east and associated imbrication fractures in overlying rocks may have been a cause of the widespread retrogression in this part of the area. The major dislocation cuts through the north-west end of the supracrustal belt and comprises gneisses transformed into finely banded blastomylonites, commonly with flinty fracture.

\section{Late pegmatites}

Pegmatites form a swarm concentrated on the southern part of the lake at $678 \mathrm{~m}$ (fig. 18). Commonly they are steeply dipping and trend between $60^{\circ}$ and $80^{\circ}$, with a sub-set trending between $100^{\circ}$ and $120^{\circ}$. The largest member of the swarm is over $3 \mathrm{~km}$ long and up to $100 \mathrm{~m}$ wide, but normally they can only be traced for up to several hundred metres and are less than $5 \mathrm{~m}$ wide. They post-date the intrusion of Tarssartôq dykes and are undeformed apart from a few which have been affected by late shears, for example, at the margins of Tarssartôq dykes. They comprise microcline, quartz, muscovite, biotite and locally garnet. Muscovite is the commonest mica and it is often finely interlayered with biotite, forming 'books' up to $1 \mathrm{~cm}$ thick. Allanite is locally found in the wall rocks of the pegmatites.

Acknowledgements. I thank Kim Møller Hansen who ably assisted me in the field and Heinrich Zahnd, pilot of the GGU-chartered Heliswiss Jet Ranger, whose skillful flying and cooperative attitude made a significant contribution to the field programme.

\section{References}

Allaart, J. H. 1976: The pre-3760 m.y. old supracrustal rocks of the Isua area, central West Greenland, and the associated occurrence of quartz-banded ironstone. In Windley, B. F. (edit.) The Early History of the Earth, 177-189. London: Wiley.

Nutman, A. P., Bridgwater, D., Dimroth, E., Gill. R. \& Rosing, M. in press: Field work on the early $(3700 \mathrm{Ma})$ Archaean rocks of the Isua supracrustal belt and adjacent gneisses. Submitted to Rapp. Grønlands geol. Unders. 